\title{
NESTING OF THE CRESTED CARACARA IN ORGAN PIPE CACTUS NATIONAL MONUMENT, ARIZONA
}

\author{
JOSEPH L. VEVERKA and TYLER H. COLEMAN, Organ Pipe Cactus National \\ Monument, 10 Organ Pipe Drive, Ajo, Arizona 85321; tyler_coleman@nps.gov
}

In the United States, breeding of the Crested Caracara (Caracara cheriway) has been documented in Florida, Texas, Louisiana, and Arizona (Morrison and Dwyer 2012, Jenness 2015). In Arizona, the caracara has been long familiar to the Tohono O'odham (Rea 2007), but the first nest reported in the scientific literature was found in 1960, in the Tohono O'odham Nation (Levy 1961). More nests were discovered there in the 1970s (Levy 1961, Ellis et al. 1988). From 1986 to 1988, Levy (1988) observed 21 nests in this area. Only two nests were known outside the Tohono O'odham Nation at that time, one west of Tucson (in 1964) and one north of Tucson (in 1988). In the last decade at least 15 active nests have been found in Arizona outside of the Tohono O'odham Nation, north and west of Tucson in the North Altar Valley and on the Santa Cruz Flats (D. Jenness pers. comm.).

Located in the Sonoran Desert immediately west of the Tohono O'odham Nation, Organ Pipe Cactus National Monument $\left(32^{\circ} \mathrm{N}, 112^{\circ} \mathrm{W}\right)$ encompasses $832 \mathrm{~km}^{2}$ and shares a 48-km border with Mexico. Huey (1942) did not record the caracara on the basis of his survey there in 1939 , but sight records have been consistent for several decades since. No caracara nests have previously been confirmed at Organ Pipe Cactus National Monument, though Levy (1988) mentioned a "vague" report of one in 1964.

Within Organ Pipe Cactus National Monument, we identified two active nest sites in 2016 and a third in 2017. All three nests were in the southernmost section of Organ Pipe, along the international border $25 \mathrm{~km}$ west of the nearest previously known nest, near Ali Chuk, Tohono O'odham Nation (Levy 1988, Figure 1). The Organ Pipe nests conform with those previously reported in Arizona, with respect to situation, habitat, and elevation (Levy 1988, 1998, Corman 2005, Jenness 2015). The Organ Pipe nest sites were in Arizona upland, Sonoran desert scrub (Brown 1982) with sparse saguaro cacti (Carnegiea gigantea). The dominant shrubs were creosote (Larrea tridentata) and triangle-leaf bursage (Ambrosia deltoidea). Saltbush (Atriplex sp.) and white bursage (Ambrosia dumosa) were present but less common. The nests ranged in elevation from 438 to $467 \mathrm{~m}$ and were placed $3.9-4.5 \mathrm{~m}$ above the ground in mature saguaros approximately $10 \mathrm{~m}$ tall. Each saguaro with a nest had nine or ten upright arms growing parallel to the main stem. Three arms and the main stem supported each nest. All nests were oriented south-southeast of the main stem of the saguaro.

In April 2016 we observed two active (sensu Postapulsky 1974) caracara nests in Organ Pipe, to which we refer as nest one and nest two, and discovered nest three $1 \mathrm{~km}$ north of site two. Nest three remained inactive in 2016. In April 2017 it was active but nest two was inactive. Nest one was active in both years. We attempted to monitor each nest at least once per month during the winter and at least twice per month in the other seasons. We documented activity at these sites from April 2016 through April 2017.

On 8 April 2016 an adult caracara was found at nest one. On 18 and 25 April, an adult was incubating. On 31 May we observed two nestlings that J. L. Morrison (pers. comm.) estimated to be about seven weeks old, on the basis of our photos. Young caracaras were not confirmed in June, but on 30 June one adult was flying toward the nest carrying a horned lizard (Phrynosoma sp.). Thirty minutes later one adult and one caracara of unknown age flushed from the ground within $200 \mathrm{~m}$ of the nest. On 13 July both adults were observed, one in the nest. On 7 September one 


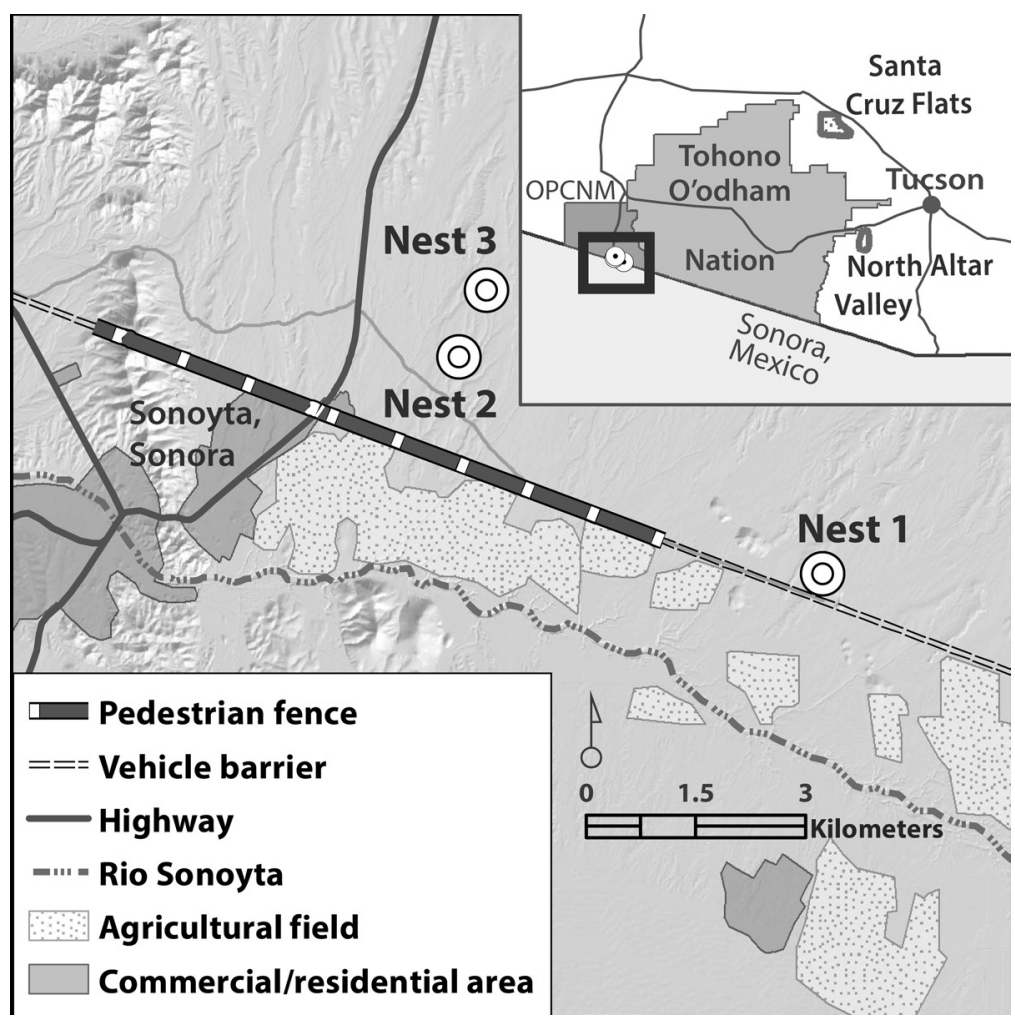

Figure 1. Approximate locations of nests of the Crested Caracara in Organ Pipe Cactus National Monument, Arizona, 2016-2017.

nestling was observed. On 5 October we observed one fledgling attempting to fly and one adult carrying a prey item to another fledgling on the ground.

On seven occasions between 14 September and 12 October we observed an adult bringing prey to nest one. Prey items included a horned lizard (Phrynosoma sp.), coachwhip snake (Masticophis flagellum), rattlesnake (Crotalus sp.), unidentified lizards, and unidentified insects.

On 16 February 2017 we observed two adults adding material to a nest in a saguaro $300 \mathrm{~m}$ south of site one (Figure 2). Because of the mixture of large sticks and small twigs this structure may have been previously used by other species. The Red-tailed Hawk (Buteo jamaicensis), Harris's Hawk (Parabuteo unicinctus), and Common Raven (Corvus corax) also build nests in large saguaros but use heavier sticks than do caracaras, which use fine twigs (Levy 1988). It is not unusual for caracaras to have alternate nests near their active nest (Levy 1988, Morrison and Dwyer 2012). On 10 March we observed two caracaras between this nest and site one, but on 21 March we found a Great Horned Owl (Bubo virginianus) in the nest. The caracaras were not seen again until 4 April, when one adult was observed in the original nest (site one).

Nest two was found $5.8 \mathrm{~km}$ west of site one and was confirmed active on 13 April 2016 when one adult was observed incubating. We observed an adult in the nest from 


\section{NOTES}

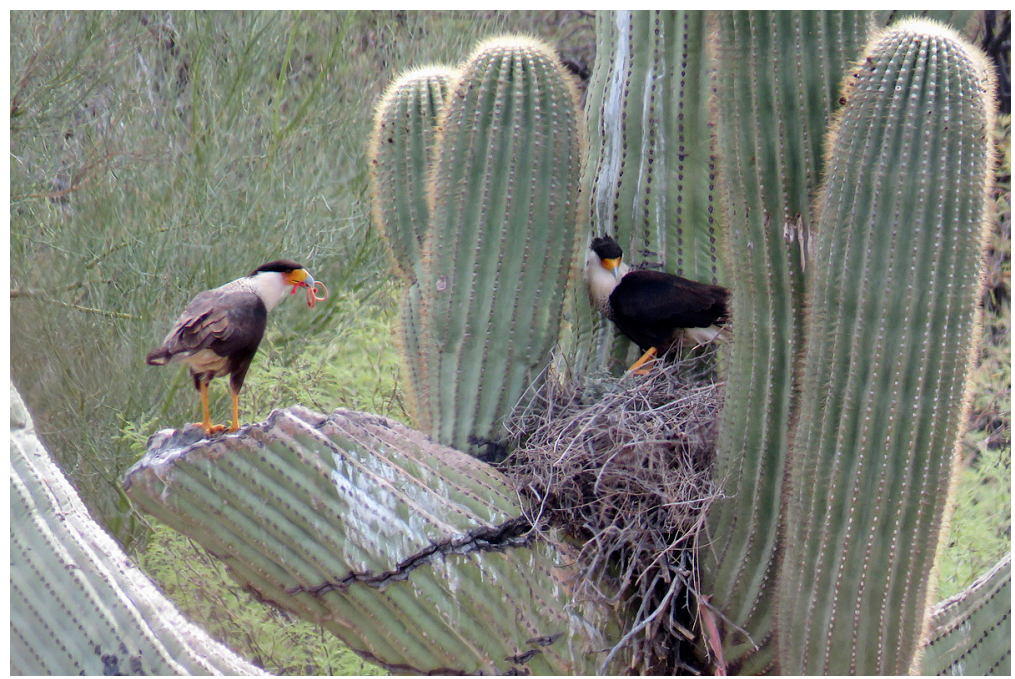

Figure 2. Two adult Crested Caracara building an alternate nest, which was soon taken over by a Great Horned Owl. February 2017, Organ Pipe Cactus National Monument, Arizona.

Photo by Tyler H. Coleman, courtesy of the National Park Service

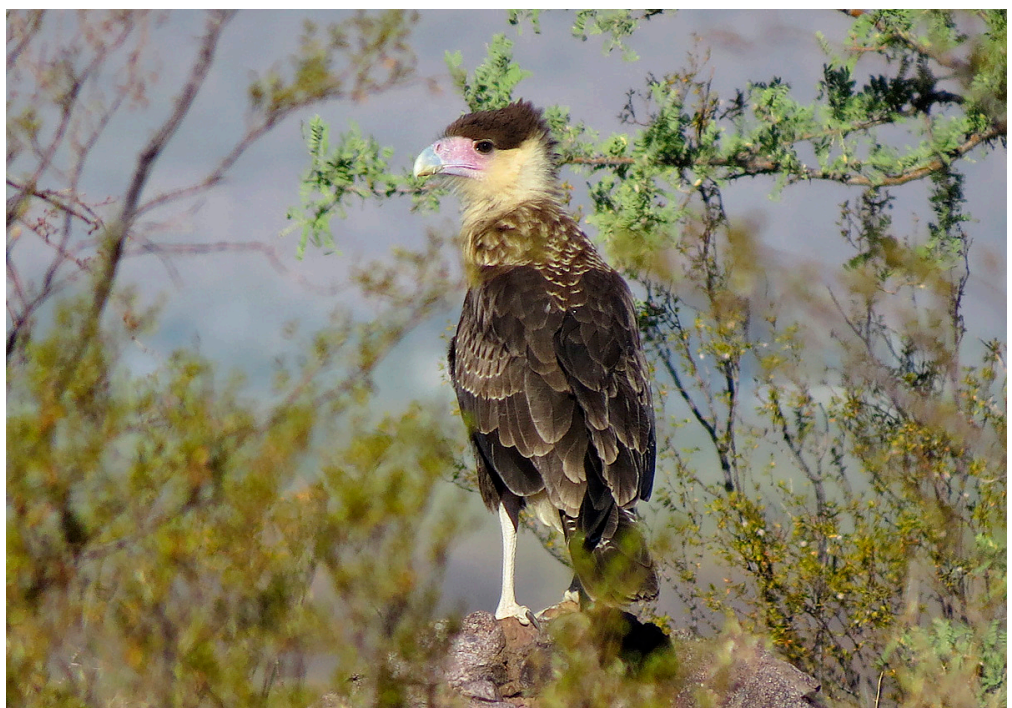

Figure 3. Fledgling Crested Caracara on the ground after an attempt to fly. October 2016, Organ Pipe Cactus National Monument, Arizona.

Photo by Tyler H. Coleman, courtesy of the National Park Service 


\section{NOTES}

18 April to 12 May. The adults were observed near the nest four times after 12 May and were last seen on 30 June. It was not known if this nest produced fledglings, but from the timing of our observations success was unlikely (Levy 1988).

We found an alternate nest (site three) $1 \mathrm{~km}$ north of site two on 6 April 2016. It contained fine nest materials commonly used by caracaras (Levy 1988). We do not know if caracaras attempted to use site three in 2016. On 11 April 2017, however, an adult was incubating at this nest and a second adult was perched nearby. Conversely, no caracaras were found at nest two at that time.

The fate of nest one's first brood in 2016 is unknown. From the size of the nestlings on 31 May they would have been mature enough to fledge before 7 June when the nest was empty. We found an incubating adult on 13 July, only 43 days after nestlings were last observed. Caracaras are known to double brood as well as to attempt a second nesting when the first fails (Morrison and Dwyer 2012). In cases of double brooding in Florida, caracaras do not start a second brood until two or three months after the first brood fledges (J. L. Morrison pers. comm.). We confirmed that two young fledged from the second attempt on 5 October (Figure 3). Successful fledging of two broods has also been found in Texas and southern Baja California, where caracaras fledged in June and incubated in August (Dickinson and Arnold 1996, Rivera-Rodriguez and Rodriguez-Estrella 1998, Morrison and Dwyer 2012). If nest one fledged two broods it would be the first instance of the caracara double brooding known in Arizona. Whether or not the first attempt failed, the success of a second attempt is the first documented in Arizona. In 2015, a pair made two failed nesting attempts on the Santa Cruz Flats (D. Jenness pers. comm.).

The discovery of caracaras nesting at Organ Pipe suggests a westward expansion of the species' range in Arizona and the United States, fitting the broad range expansion described by Jenness (2015). The nesting in Organ Pipe is possibly the result of the availability of protected nest sites within the monument and opportunities for foraging in agricultural fields in adjacent Mexico, from which direction we saw an adult bringing prey on seven occasions. All three nests found at Organ Pipe were located near the international border, and searches in 2016 and early 2017 did not reveal any nests or caracaras north of site three. On 18 November 2017, Organ Pipe staff witnessed two caracaras foraging on the ground in an agricultural field in Mexico between nest one and two. Selection of nest sites in Sonoran desert scrub near agricultural fields or free-ranging livestock is consistent with observations elsewhere in Arizona (Jenness 2015). In Florida, caracaras nest in higher concentrations around cattle ranches, often within $2 \mathrm{~km}$ of one another (Morrison and Humphrey 2001). In Baja California, the caracara's nest success and high productivity might be related to the availability of suitable nest supports and human-provided food sources (Rodriguez-Estrella 1996). Caracaras adapt well to moderate habitat changes (Rodriguez-Estrella 1996), and minor disturbance by humans is unlikely to cause desertion of eggs or young (Morrison and Humphrey 2001). Therefore further range expansion in Arizona and the Sonoran Desert might be expected in areas with similar resources.

\section{LITERATURE CITED}

Brown, D. E. 1982. Biotic Communities of the American Southwest: United States and Mexico. Univ. Utah Press, Salt Lake City.

Corman, T. E. 2005. Crested Caracara (Caracara cheriway), in Arizona Breeding Bird Atlas (T. Corman and C. Wise-Gervais, eds.), pp. 152-153. Univ. New Mexico Press, Albuquerque.

Dickinson, V. M., and Arnold, K. A. 1996. Breeding biology of the Crested Caracara in south Texas. Wilson Bull. 108:516-523.

Ellis, D. H., Smith, D. G., Whaley, W. H., and Ellis, C. H. 1988. Crested Caracara, in Proceedings of the Southwest Raptor Management Symposium and Workshop 


\section{NOTES}

(R. L. Glinski, B. G. Pendleton, M. B. Moss, M. N. Le Franc, Jr., B. A. Millsap, and S. W. Hoffman, eds.), pp. 119-126. Sci. Tech. Ser. 11, Natl. Wildlife Fed., Washington, D.C.

Huey, L. M. 1942. A vertebrate faunal survey of the Organ Pipe Cactus National Monument, Arizona. Trans. San Diego Soc. Nat. Hist. 9:353-376.

Jenness, D. 2015. Crested Caracara in Arizona: Background and recent expansion. Arizona Birds Online; http://arizonabirds.org/journal/crested-caracara-arizonabackground-recent-expansion.

Levy, S. H. 1961. The Caracara nesting in Arizona. Auk 78:99; doi 10.2307/4082248.

Levy, S. H. 1988. Status and distribution of the Crested Caracara in Arizona. Report to Arizona Game and Fish Department, Phoenix, AZ 85086.

Levy, S. H. 1998. Crested Caracara, in The Raptors of Arizona (R. L. Glinski, ed.), pp. 115-117. Univ. Ariz. Press, Tucson.

Morrison, J. L., and Dwyer, J. R. 2012. Crested Caracara (Caracara cheriway), in The Birds of North America Online (P. G. Rodewald, ed.), no. 249. Cornell Lab. Ornithol.. Ithaca, NY; doi 10.2173/bna.249

Morrison, J. L., and Humphrey, S. R. 2001. Conservation value of private lands for Crested Caracaras in Florida. Conserv. Biol. 15:675-684; doi 10.1046/j.15231739.2001.015003675.x.

Postapulsky, S. 1974. Raptor reproductive success: Some problems with methods, criteria, and terminology, in Management of Raptors: Proceedings of the Conference on Raptor Conservation Techniques (F. N. Hamerstrom, B .E. Harrell, R. R. Olendorff, eds.), pp. 21-31. Raptor Res. Rep. 2, Raptor Res. Found., Vermillion, SD.

Rea, A. M. 2007. Wings in the Desert: A Folk Ornithology of the Northern Pimans. Univ. Ariz. Press, Tucson.

Rivera-Rodriguez, L. B., and Rodriguez-Estrella, R.1998. Breeding biology of the Crested Caracara in the cape region of Baja California, Mexico. Raptor Res. 31:228-233.

Rodriguez-Estrella, R. 1996. Response of Common Black Hawks and Crested Caracaras to human activities in Mexico, in Raptors in Human Landscapes (D. M. Bird, D. Varland, and J. J. Negro, eds.), pp. 355-366. Academic Press, London; doi 10.1016/B978-012100130-8/50035-3.

Accepted 21 February 2018 